\title{
GREEN BRAND POSITIONING FOR ORGANIC FOOD: A CONTENT ANALYSIS OF CORPORATE WEBSITES
}

\author{
Mihai STOICA* \\ Bucharest University of Economic Studies, Romania
}

\begin{abstract}
The purpose of this paper is to provide a perspective on the positioning bases of the green brands present on the organic food market. The research method is the content analysis of secondary data sources. The study was based on the analysis of the informational content available on the corporate websites of green brands in the portfolio of processing companies present on the Romanian market. This study identified 18 positioning bases for the investigated green brands. The positioning bases belong mainly to the category of attributes, these being in particular specific characteristics of organic food. The study notes the existence of specific positioning bases for organic food brands. The results can help practitioners to communicate brand positioning in the online environment by developing appropriate strategies.
\end{abstract}

Keywords: green brand positioning, online environment, content analysis, organic food. JEL classification: M31, Q57, M10.

\section{Introduction}

Consumer preferences and government policies increasingly favor a balanced approach by companies regarding the environment, with managers paying more attention to strategic decisions that may have an impact on environmental issues (Hollensen, 2011; Zameer et al., 2020). In addition to government and stakeholder pressure, many companies are adopting a green marketing strategy due to the actions of the competition (Leonidou et al., 2015; Iyer et al., 2019; Taherdangkoo et al., 2019; Tjahjadi et al., 2020), the high costs of disposing of environmentally harmful products or waste (Mishra and Sharma, 2010), or even in order to apply their business philosophy.

This way, Ginsberg and Bloom (2004) argue that there is no marketing strategy that is right for every company. Therefore, strategies should be adapted to the particularities of the market, the intensity of competition and the level of

\footnotetext{
* Corresponding author. Address: Marketing Department, Faculty of Marketing, The Bucharest University of Economic Studies, 6 Piata Romana, 1st district, Bucharest, 010374, Romania, Tel. 0749.087.348, Email mihai.stoica.91@gmail.com
} 
concern for the environment of consumers. In the case of the organic market, as is the case of other markets, a particular approach to marketing strategies is needed.

By approaching green marketing, companies have the opportunity to capitalize on environmental concerns in order to position their brands with the purpose of gaining new competitive advantages on new markets. Consequently, the ideas and values specific to green marketing can become a new way of positioning a brand, which also requires adapting the concept to the issues and particularities of the green market.

The topic of green brand positioning has drawn the attention of researchers (Hartmann et al., 2004; Hartmann and Ibanez, 2005; Haung et al, 2014; Suki, 2016; Wang, 2016; Gong et al., 2020; Lin and Zhou, 2020; Bursan et al., 2021), some specialists even considering that brand positioning is the most tangible discrepancy between green and conventional marketing (Rex and Baumann, 2007).

One of the most competitive areas in which green brands enjoy consumer appreciation and recognition is the organic food area. From a niche market to an autonomous sector, the organic food market is constantly growing (Willer and Lernoud, 2019), which has led to the expansion of the number of organic products and, implicitly, the number of green brands. Even in these conditions, the subject of the positioning of organic food brands has not been widely exploited in research (Zanoli and Naspetti, 2006; Padel and Gössinger, 2008; Barrena and Sánchez, 2010; Zander et al., 2010; Ćirić and Prodanović, 2013; von Meyer-Höfer et al., 2013, 2015; Vlahović and Šojić, 2017).

Zanoli and Naspetti (2006) state that the green brand positioning is mainly based on product attributes. von Meyer-Höfer et al. (2015) also have an approach based on the attributes of the products, starting from the attributes that result from the observance of the legislative norms. Because organic food is primarily characterized by credentials, organic certification is essential and supports brand positioning (Zanoli and Naspetti, 2006; Janssen and Hamm, 2011; von Meyer-Höfer et al., 2015). Instead, the benefits are not so widely studied in the field of organic food, especially the emotional and symbolic benefits. By comparison, the rational benefits are more frequently analyzed due to the close connection with the specific attributes and characteristics of organic food (Wright and McCrea, 2007; Naspetti and Zanoli, 2009). However, in the literature, there is no extended vision on how specific positioning bases are used, as well as on their importance in defining the brand positioning. The relationship between attributes, benefits, values or other possible associations and brand positioning is still poorly highlighted in the literature.

This paper aims to investigate the positioning bases that organic food brands communicate through corporate websites. Starting from the studies conducted by Wang $(2016,2017)$ in the field of green brand positioning in the online environment, and by deepening the typologies of the researched positioning strategies (Hartmann et al., 2004, 2005), the paper intends to identify a number of alternatives used in the online environment by green brands.

The topic of green brand positioning was studied on the market of organic food in Romania. Still needing efforts to make marketing more efficient and more adapted to the specifics of the market, but also to educate and attract consumers to adopt a pro-ecological behavior (Stoica et al., 2020), Romania has made obvious progress in this direction, especially due to the EU's contribution to the development of 
this sector. The research was conducted among organic food processors, due to their concerns in the direction of building their own brands.

This study contributes to the research of the positioning of green brands in the dynamic field of organic food. The study notes the existence of specific positioning bases for the brands present in this market, offering a series of solutions for companies that want to develop a brand that stands out in the multitude of green brands. Also, by exploring the online environment, the study provides directions for communicating brand positioning through this channel, which has become essential nowadays.

\section{Literature review}

\section{Green brand positioning}

Having as a starting point the approach offered by classic marketing (Ries and Trout, 2001), the concept of green brand positioning has been enriched with specific values and principles of green marketing, integrating the preoccupation for the environment and for the needs of current and future generations of consumers.

This concept is often presented as having strong implications in the field of marketing communication. From this perspective, green brand positioning implies an active communication and entails the differentiation of the brand by highlighting its environmental attributes (Hartmann et al., 2005). Moreover, Suki (2016) considers that the green brand positioning is achieved through green attributes being integrated into active communication campaigns, which could induce a more positive perception of green brands amongst consumers. These views are in line with the theories of those experts who argue that positioning emphasizes brand communication (Ries and Trout, 2001; Kapferer, 2008). In this regard, the role of a green brand is exploited to help consumers differentiate them from other similar brands with the same functions (Rahbar and Wahid, 2011).

However, some authors (Saha and Darnton, 2005) believe that the position of a green brand should be considered from the perspective of the perception on its ecological reputation, rather than how it compares to competing brands. This is because a brand may be ecologically superior, but it may not have the ability to convey green attributes and benefits as well as competing brands. Therefore, establishing a position in relation to competition requires paying special attention to the elements of the marketing mix, especially the communication strategy.

Nevertheless, the opinions presented above do not capture the full complexity of the issue of green brand positioning, with particular emphasis on marketing communication, which is important only after establishing the brand positioning, as well as other elements of the marketing mix (Wilson and Gilligan, 2005). The importance of positioning strategy derives from the fact that it is considered the essence of the marketing mix (Schiffman and Kanuk, 2007).

In terms of the impact on the elements of the marketing mix, the green brand positioning is a critical strategy for a brand (Huang et al., 2014), which has the role of influencing the perceptions of the consumers targeted by the green brand initiatives, providing an essential basis for differentiating the green brand from its competitors.

The consumer is particularly important in the process of positioning, and it is necessary to constantly refer to it in order to choose and maintain the desired green position. In this sense, all actions of an organization that wants to position itself 
as environmentally friendly must meet consumer expectations (Polonsky and Rosenberger III, 2001). Consequently, the incorporation of environmental aspects in the brand positioning strategy must take into account the target consumer segment. For example, Belz and Schmidt-Riediger (2009) consider that organizations that are positioned in the price and/or premium quality segment are more inclined to adopt green marketing strategies than those that try to differentiate by price.

Starting from a series of well-known opinions in the field of brand positioning (Ries and Trout, 2001; Kapferer, 2008), Huang et al. (2014) considers the green brand positioning part of the brand identity and the value proposition regarding green attributes, which must be actively communicated to the target audience. Thus, in order to gain the desired position for a green brand, marketing communication must be used to create a distinct identity in the minds of consumers. In addition to providing the attributes and functional benefits desired by consumers, green brand positioning also implies satisfying emotional needs and building an affective relationship with the customer (Coddington, 1993, cited in Hartmann et al., 2005). Therefore, green brand positioning can be considered a subset of attributes, benefits and environmental values that have the ability to convince green customers to be loyal to green products and brands (Hartmann et al., 2005; Amin et al., 2015).

However, it is not only the green elements that are important in establishing the positioning of a green brand. It is also necessary to establish the degree to which green attributes are used to communicate to the market how the product/brand differs from existing ones (Driessen et al., 2013). Thus, some specialists (Mera, 2003; Belz and Karstens, 2005; Driessen et al., 2013) consider that this decision entails establishing the need to position the green brand on the basis of the combination between green attributes and traditional attributes, specific to conventional products, and the determination of which of the two attribute categories is the dominant one.

In conclusion, a well-implemented green brand positioning strategy can, overall, lead to a more favorable perception of the brand, thus providing support for the overall marketing approach (Hartmann et al., 2005). Positioning must give to a green brand a position to convey its ability to reduce the negative impact on the environment and human health, while not forgetting to best meet the basic needs of consumers.

\section{Green brand positioning in the field of organic food}

While organic food markets are still considered a relatively small niche, opportunities to position organic products are found in a wide range of approaches. The key to understanding the nature of these alternatives is to know the value created by offering eco-friendly products to the customer and by including them in a company's value proposition (Dean and Pacheco, 2014).

Companies present on the organic food market can focus primarily on the characteristics of the product, having the opportunity to highlight the organic or natural composition of the product and the fact that it does not contain food additives. Also, if we refer to intangible attributes, the corporate/brand identity is communicated and the philosophy or nature of the production process can be highlighted: the fact that food is traditionally manufactured by a family company, which is focused on animal and environmental welfare (Brüggenwirth, 2006). If some or most of the attributes are of a superior level, the organization may want to position its brand as superior or as a technological leader. 
Zanoli and Naspetti (2006) state that the green brand positioning is mainly based on certain attributes of products, either positive (better taste, authentic, natural etc.) or negative (without chemicals, non-GMOs, no artificial flavors, no preservatives, etc.). At EU level, brands choose to position themselves through attributes which are also regulated by the legislation in the field. These specific attributes of organic products were analyzed by von Meyer-Höfer et al. (2015). Often, these attributes are held by all certified organic products, therefore they can represent points of differentiation only in a few cases. Instead, they often need to be associated with other attributes or other positioning bases. Also, in the case of the attributes regulated by EU legislation, it is very important how they are represented through the marketing mix, as they can be put in an unique light, especially through the way the communication strategy is implemented.

By studying the literature, other attributes were identified, compared to those included in EU regulations, which are often used to position brands of organic products. Among these green attributes we mention: good/authentic/ intense/natural taste (Fillion and Arazi, 2002; Naspetti and Zanoli, 2009; Asioli et al., 2014; von MeyerHöfer et al., 2015; Hemmerling et al., 2016; Sidali et al., 2016), high nutritional content (Naspetti and Zanoli, 2009; Sidali et al., 2016); ecological packaging (Magnier et al., 2016; Steenis, 2019); local/regional production (Zander and Hamm, 2010; Roosen et al., 2012; Sidali et al., 2016).

On the other hand, positioning through benefits is one of the most natural alternatives that a brand can use to gain a certain position in the minds of consumers. Therefore, studying the reasons for buying and the benefits desired by consumers could support the brand in choosing a successful position on this market. Research has found that occasional consumers have become loyal buyers of organic products only when they were convinced of the positive benefits for health, environment and animal welfare (Wright and McCrea, 2007).

We must also not forget the food safety guaranteed by organic products. Food safety is linked to the risks perceived by consumers regarding the ingestion of "harmful substances" through their diet (Naspetti and Zanoli, 2009). Organic food should be positioned is such a way as to ensure food safety for those preventionfocused consumers who want safe, pesticide free food and consistent quality. Conversely, promotion focused consumers are trying to attain two consequences: one is the egoistic goal of individual health, a cheerful life and classic or old-fashioned aesthetics, and the other is related to altruism or an interdependence-others orientation (Chen et al., 2015). Finally, it can be difficult to distinguish whether buyers are behaving out of altruism, as a result of a sense of individual responsibility or a desire to signal a certain social status, because motivations are likely to be interrelated (Dean and Pacheco, 2014).

Due to the fact that organic products favor a strong emotional involvement (Zanoli and Naspetti, 2006), compared to other food products, green brands may choose to be associated with emotional/symbolic benefits. Marketers could successfully position organic products based on emotional and symbolic benefits, related to the sensory pleasure of consuming organic food and feelings of security, satisfaction and pride derived from improving health for themselves and their family (Bozga and Cristea, 2016).

An essential feature of organic products is related to the organic certification scheme that can be associated with the brand. Thus, being symbolic products that 
consumers perceive mainly on the basis of credentials, such as the logo specific to the certification body (eco-label), it is extremely important that the product be positioned in terms of terminal value (Zanoli and Naspetti, 2006).

These tools give consumers the opportunity to choose between products with similar visual elements, differentiating between them. Mentioned among extrinsic quality indices, they serve as signs of quality before any other experience. They act as trusted creators and are linked to the level of consumer experience (Bredhal, 2003, cited in Naspetti and Zanoli, 2005). Using other logos specific to different certification schemes in addition to the mandatory logo can be an effective strategy if consumers associate added value to the additional logo, such as stricter standards, higher food security or any other aspect of perceived quality (Janssen and Hamm, 2011; von Meyer-Höfer et al., 2015).

\section{Research methodology}

The purpose of this exploratory research is to study the content of the positioning communicated for organic food brands that are in the portfolio of certified organic food processors in Romania. The study aims to identify the bases of green brand positioning, as well as their importance in terms of communicating the brand's position in the online environment.

\section{Research method}

The research method is the content analysis of secondary data sources in the online environment. During the process of data collection and analysis, an exploratory study was conducted to identify, analyze and describe the positioning bases used by the identified brands. The study was based on the analysis of the informational content available on corporate websites.

\section{Defining the target population and the sampling frame}

The target population consists of Romanian companies that hold an organic certification granted by an accredited certification body. Among the operators registered in organic farming (producer, processor, trader, importer, exporter, operator in spontaneous flora, operator in aquaculture), the most susceptible economic agents concerned with the development of organic brands are processors. Thus, the target population consists of all processing companies for which the organic certificate is published on the official website of the Ministry of Agriculture and Regional Development (MADR, 2018).

In addition to holding an organic certification and to being included in the category of processors, additional selection criteria were established so that the companies included in the sampling frame would meet the purpose of the research:

a. The company must have an official website;

b. The company must process and/or package organic products under its brand;

c. The offer available on the official website must include organic food products;

d. Products sold under their brand must be addressed to individual customers. 
The fulfillment by the companies of the last three selection criteria was verified exclusively on the basis of the information presented on the website. In the absence of this information, the company is excluded from the sampling frame.

\section{Collecting data on the target population and establishing the sampling frame}

In order to identify the companies processing organic products that meet the criteria mentioned above, between February 9 and 17, 2020, the MADR website was accessed in order to select processors that have an organic certificate issued in 2018. Analyzing the data published by the certification bodies, 148 processing enterprises registered in organic farming in 2018 were identified (one of the companies was eliminated because it was present twice).

For the 147 processing companies, the existence or non-existence of an official website was identified. In this sense, between April 7 and 10, 2020, the Google search engine was used to identify the websites. It was intended that the identified website should clearly specify the name of the company in one of the sections of the website (usually, the name of the company was identified in the sections "Terms and Conditions" or "Contact"). Following this stage, in the case of 54 companies an official website has not been identified, while in the case of another 6 companies it was found that the website is under maintenance, under construction or currently unavailable. After this stage, the other three criteria (b, c and d) were applied, as we can observe in Table 1.

\section{Table 1. Selection of the sampling frame}

\begin{tabular}{|c|c|c|}
\hline Selection & Variables investigated & $\mathbf{N}$ \\
\hline & Target population & 147 \\
\hline $\mathbf{A}$ & $>$ Companies for which an official website has not been identified & 54 \\
\hline A & $\begin{array}{l}\text { >Companies whose website is in maintenance, in construction or currently } \\
\text { unavailable }\end{array}$ & 6 \\
\hline A & >Companies for which an official website has been identified, of which: & 87 \\
\hline B & >>Companies that do not offer food products & 3 \\
\hline B & > Companies that offer food products, of which: & 84 \\
\hline $\mathbf{C}$ & >>>Companies for which no organic products have been identified & 14 \\
\hline C & $\begin{array}{l}\text { > >Companies for which organic products have been identified, of } \\
\text { which: }\end{array}$ & 69 \\
\hline D & $\begin{array}{l}\text { >>>>Companies for which it has not been identified on the website that } \\
\text { sell their products to individual customers }\end{array}$ & 10 \\
\hline \multirow[t]{2}{*}{ D } & $\begin{array}{l}\text { \>>Companies for which it has been identified on the website that } \\
\text { sell their products to individual customers }\end{array}$ & 59 \\
\hline & Sampling frame & 59 \\
\hline
\end{tabular}

Finally, 59 organic certified processing companies remained in the investigated group, whose website was analyzed. 


\section{Data collection and analysis}

Each of the 59 corporate websites was accessed and viewed in order to determine what information is related to the green orientation of the company and the brand and what information is related to organic products. The entire content (in the form of text) present on the website was analyzed, but particular attention was paid to the elements that could represent evidence of the use of positioning bases in order to communicate the chosen positioning strategy. The gathering of information from the websites took place between April 7 and 30, 2020.

Content analysis was performed using nVivo 12 software, which facilitated the analysis of information extracted manually from corporate websites. The selected information was considered the main data for analysis. The importance of using nVivo software in conducting exploratory research has been pointed out in numerous papers. Also, a wide variety of research questions can be answered by exploring communication in the online environment (Jackson and Bazeley, 2019).

Content analysis was used to classify the categories and concepts that appeared in the collected data. The research was based on codes created by the researcher, based on the topics and themes identified in the selected text on corporate websites. At a first analysis of the selected text, 47 codes were created. After that, the text was read for the second time, and the codes were refined, being grouped into more general categories, which could better represent the content identified on all websites analyzed. Thus, in the end, 18 codes resulted. The nVivo software was used to help encode. Examples of codes can be found in Table 2.

\section{Table 2. Examples of codes built on the bases used to position an organic food brand}

\begin{tabular}{|c|c|}
\hline Code name & Content identified on the website \\
\hline Raw food & $\begin{array}{l}\text { "This raw vegan product, obtained by concentrating in vacuum at a tempera- } \\
\text { ture of max } 42^{\circ} \mathrm{C} \text {, without pasteurization, has a high content of natural fruit } \\
\text { sugars, rich in vitamins and antioxidants, without added sugar, preservatives, } \\
\text { additives or dyes. The manufacturing process ensures the preservation of } \\
\text { nutrients, phytonutrients and aromas of grapes" (RAW-E) (Phenalex, 2020) }\end{array}$ \\
\hline $\begin{array}{l}\text { Maintain } \\
\text { regaining } \\
\text { and ado } \\
\text { healthy li }\end{array}$ & $\begin{array}{l}\text { "In order to grow up beautiful and harmonious, the child must have a healthy } \\
\text { base structure, which will allow him to enjoy all the special moments of child- } \\
\text { hood. } 1 \mathrm{BIO} 3 \text { milk is enriched with } 21 \text { vitamins and minerals, for the balanced } \\
\text { development of the little ones" (OLYMPUS 1BIO3) (Fabrica de Lapte Brașov, } \\
2020)\end{array}$ \\
\hline $\begin{array}{r}\text { Naturalne } \\
\text { puri }\end{array}$ & $\begin{array}{l}\text { "In obtaining the wines from this range, we used only what Mother Nature } \\
\text { offered us to the fullest: earth, air, water, sun. These are the only ingredients, } \\
\text { used naturally to get the most out of each grape" (BUDUREASCA ORGANIC) } \\
\text { (Viile Budureasca, 2020) }\end{array}$ \\
\hline $\begin{array}{r}\text { Loca } \\
\text { pro }\end{array}$ & $\begin{array}{l}\text { "The factory continues the local tradition of trout processing by smoking. } \\
\text { Valeputna, the Premium brand under which we sell our products, is a tribute to } \\
\text { the first trout farm in Romania - founded here in } 1896 \text { under the name of } \\
\text { "Valeputna Fischbruthutte" - and to the artisans to whom we owe the secrets of } \\
\text { the recipe for smoking. In Putna Valley was invented the local delicacy known } \\
\text { as Cobza, smoked trout with fir cones and beechwood, dressed in fir-tree } \\
\text { branches and tied in hazel twigs" (VALE PUTNA) (Quality Natural, 2020) }\end{array}$ \\
\hline Prod & $\begin{array}{l}\text { "Organic milk is carefully tested and verified at each factory reception. The } \\
\text { tests monitor both milk quality (fat, protein, density) and microbiological safety } \\
\text { (germ loading, accidental contamination)" (ZUZU BIO) (Albalact, 2020) }\end{array}$ \\
\hline
\end{tabular}




\section{Research results}

\section{Positioning bases used for organic food brands}

Based on the content analysis, there were 18 elements (codes) that can be positioning bases for green brands (see Table 3). Also, in the elaboration of the codes, the studies carried out on this subject were taken into account (Hartmann et al., 2005; Naspetti and Zanoli, 2009; Zander and Hamm, 2010; Insch, 2011; Juwaheer et al., 2012; Ćirić and Prodanović, 2013; Driessen et al., 2013; Haryanto and Budiman, 2014; Huang et al., 2014; Matthes et al., 2014; Amin et al., 2015; von Meyer-Höfer et al., 2015; Wang, 2016, 2017; Vlahović and Šojić, 2017), specifying that the subject of positioning the brands present on the market of organic food products is weakly highlighted in the literature.

\section{Table 3. The results of the content analysis}

\begin{tabular}{|c|c|c|}
\hline No. & Elements $(n=18)$ & Concepts involved \\
\hline 1. & $\begin{array}{l}\text { Absence of chem- } \\
\text { ical pesticides } \\
\text { and mineral ferti- } \\
\text { lizers }\end{array}$ & $\begin{array}{l}\text { without the presence of pesticides, insecticides, synthetic ferti- } \\
\text { lizers or other chemicals; natural fertilizers; natural processes for } \\
\text { nutrients and pests, diseases or weed control; natural methods } \\
\text { of soil care; }\end{array}$ \\
\hline 2. & Animal welfare & $\begin{array}{l}\text { protection of habitats and natural living conditions; animals } \\
\text { raised freely in clean areas with natural food sources; animals } \\
\text { fed and bred according to the standards imposed by EU regula- } \\
\text { tions; }\end{array}$ \\
\hline 3. & $\begin{array}{l}\text { Brand/product } \\
\text { exclusivity }\end{array}$ & $\begin{array}{l}\text { limited series; locally/worldwide unique product; premium/super- } \\
\text { premium brand; }\end{array}$ \\
\hline 4. & $\begin{array}{l}\text { Contact with } \\
\text { nature }\end{array}$ & $\begin{array}{l}\text { care for nature; in harmony with nature; natural environment } \\
\text { (open-air, pastures, mountain landscape etc.); }\end{array}$ \\
\hline 5. & $\begin{array}{l}\text { Environment } \\
\text { protection }\end{array}$ & $\begin{array}{l}\text { protected natural area; ecosystem; preserving the quality of the } \\
\text { environment; ecologically sustainable system; sustainable de- } \\
\text { velopment; low impact on the environment; environmental man- } \\
\text { agement sustainability; crop rotation; protects the soil and eco- } \\
\text { systems; }\end{array}$ \\
\hline 6. & Fre & $\begin{array}{l}\text { make-to-order production; short time interval between harvesting } \\
\text { and delivery to the customer; product made from fresh raw ma- } \\
\text { terials; storage system; packaging methods; short supply chains; }\end{array}$ \\
\hline 7. & $\begin{array}{l}\text { Local/regional } \\
\text { production }\end{array}$ & $\begin{array}{l}\text { local product/ingredient; short supply chains; tradition/Romanian } \\
\text { traditions; local varieties; local processing tradition; local re- } \\
\text { sources; manufactured in Romania; authentic Romanian taste; } \\
\text { rural environment; full Romanian capital/Romanian company; } \\
100 \% \text { Romanian product/brand; sustainable development of the } \\
\text { village and the country; local/small farms; original/authentic } \\
\text { products; products "like at my mother's house"; old/local recipes, } \\
\text { collected and passed down from generation to generation; rural } \\
\text { tradition; Romanian cuisine; }\end{array}$ \\
\hline 8. & $\begin{array}{l}\text { Low number of } \\
\text { chemicals and } \\
\text { non-GMOs }\end{array}$ & $\begin{array}{l}\text { without food additives, enhancers, stabilizers, GMOs, artificial } \\
\text { sweeteners, emulsifiers, preservatives, dyes, artificial flavors, } \\
\text { thickening/ growth agents etc.; products as close as possible to } \\
\text { the natural state; do not contain traces of antibiotics, insecticides } \\
\text { etc.; }\end{array}$ \\
\hline
\end{tabular}




\begin{tabular}{|c|c|c|}
\hline No. & Elements $(n=18)$ & Concepts involved \\
\hline 9. & $\begin{array}{l}\text { Low resource } \\
\text { consumption and } \\
\text { use of renewable } \\
\text { energy }\end{array}$ & $\begin{array}{l}\text { use of by-products; separate collection of rainwater; alternative } \\
\text { energy sources (vegetable oil, solar panels etc.); control of energy } \\
\text { consumption; CO2 absorption; renewable resources; food waste } \\
\text { reduction; }\end{array}$ \\
\hline 10. & $\begin{array}{l}\text { Maintaining or } \\
\text { regaining health } \\
\text { and adopting a } \\
\text { healthy lifestyle }\end{array}$ & $\begin{array}{l}\text { healthy lifestyle; healthy product; diet; immunity; nutrition; bal- } \\
\text { anced diet; beneficial effects on the body (increased immunity, } \\
\text { energy supply etc.); healthy diet; physical well-being; vegan/ } \\
\text { vegetarian diet; }\end{array}$ \\
\hline 11. & $\begin{array}{l}\text { Manufacturing } \\
\text { technology and } \\
\text { production/ } \\
\text { processing } \\
\text { process } \\
\end{array}$ & $\begin{array}{l}\text { meticulous processing; minimal processing; traditional methods; } \\
\text { delicate pressing; natural fermentation process; artisanal methods; } \\
\text { without heat treatment; cold pressing; slow grinding; modern } \\
\text { equipment and automation; production laboratories; technological } \\
\text { system; }\end{array}$ \\
\hline 12. & $\begin{array}{l}\text { Naturalness and } \\
\text { purity }\end{array}$ & $\begin{array}{l}\text { natural product; pure product/ingredient; } 100 \% \text { natural; intact } \\
\text { natural properties; virgin soils; non-counterfeit products; unde- } \\
\text { tectable levels of residues; simplicity; }\end{array}$ \\
\hline 13. & $\begin{array}{l}\text { Nutritional and } \\
\text { sanitary values }\end{array}$ & $\begin{array}{l}\text { rich content of minerals, antioxidants, fiber, vitamins, proteins, } \\
\text { polyunsaturated fatty acids, macro and micro nutrients and } \\
\text { phytonutrients etc.; low acidity; vegetable source of protein, fiber } \\
\text { etc.; product of high nutritional value; superfood; minimum fruit } \\
\text { content; food with integral value; whole product; }\end{array}$ \\
\hline 14. & $\begin{array}{l}\text { Positive emotions } \\
\text { and feelings }\end{array}$ & $\begin{array}{l}\text { good feeling; positivity; harmony; inner peace; calm state; relaxa- } \\
\text { tion; the joy of life; }\end{array}$ \\
\hline 15. & Quality & $\begin{array}{l}\text { quality product/ingredient; quality standards (ISO 9001, ISO } \\
22000, \text { FSSC 22000, etc.); premium/super-premium quality; } \\
\text { superior quality compared to conventional products; exceptional } \\
\text { varieties; verified/selected raw material suppliers; integrated quality } \\
\text { system; quality assurance; certified quality; quality control in the } \\
\text { supply chain; qualitative selection; quality assurance; total quality } \\
\text { assurance; permanently controlled quality; }\end{array}$ \\
\hline 16. & Raw food & $\begin{array}{l}\text { not processed by temperatures above } 42^{\circ} \mathrm{C} \text {; raw food; minimally } \\
\text { processed items; preserving everything that is best from nature } \\
\text { (nutrients, phytonutrients, flavors etc.); raw vegan product; without } \\
\text { pasteurization; }\end{array}$ \\
\hline 17. & Safety & $\begin{array}{l}\text { own laboratory; food safety; laboratory analyzes: physical-chemical, } \\
\text { microbiological and contamination; analysis bulletins; checking } \\
\text { the quality of the raw material and the finished product; internal } \\
\text { and external analysis plan; certified and accredited laboratory; } \\
\text { control system; traceability; health rules; }\end{array}$ \\
\hline 18. & Taste & $\begin{array}{l}\text { savory taste; delicious taste; distinctive taste; maximum flavor; } \\
\text { retains primary/natural flavors; pure taste; better taste; authentic } \\
\text { taste; intense taste; delight for the senses/explosion of delight for } \\
\text { the taste buds; fine taste; real fruit taste; perfect taste; fruity taste; }\end{array}$ \\
\hline
\end{tabular}

As we can see, most of the elements identified based on content analysis are characteristic of the products that represent the brand, being largely their attributes. We can identify both attributes that are rather specific to organic food, such as: "absence of chemical pesticides and mineral fertilizers" or "low number of chemicals and non-GMOs", as well as attributes that can be representative of any product food: "taste", "quality", "freshness" or "local/regional production". Also, the variables in the category of benefits are lower in number compared to those in the category of attributes. 
Frequency of the positioning bases used to communicate the positioning strategy for organic food brands

Table 4 shows the frequency of occurrence of the codes, as well as the number of references for each code. Also, the share of these codes among the analyzed companies was established.

More than half of the brands choose to communicate elements related to the quality of organic products through the official website. This is not necessarily an attribute that can be associated exclusively with organic products (differentiation point), but can be considered an important positioning base for a green brand, as they usually choose to position themselves on the premium or super-premium segment. Also, an equally important variable is "maintaining or regaining health and adopting a healthy lifestyle", this being identified on $54 \%$ of the websites. The benefits of organic food for the body and general health, as well as the contribution to a healthy lifestyle and a balanced diet, are among the elements that the brands present on their websites.

Table 4. Frequency of codes and references among companies included in the investigated group

\begin{tabular}{|c|l|c|c|c|}
\hline No. & \multicolumn{1}{|c|}{ Code/concept name } & $\begin{array}{c}\text { No. of } \\
\text { companies for } \\
\text { which the code } \\
\text { has been } \\
\text { assigned }\end{array}$ & $\begin{array}{c}\text { No. of } \\
\text { references } \\
\text { made on } \\
\text { each code }\end{array}$ & $\begin{array}{c}\text { Share of the no. of } \\
\text { companies for } \\
\text { which the code was } \\
\text { assigned in the total } \\
\text { no. of companies }\end{array}$ \\
\hline 1 & $\begin{array}{l}\text { Absence of chemical pesticides } \\
\text { and mineral fertilizers }\end{array}$ & 5 & 9 & $8 \%$ \\
\hline 2 & Animal welfare & 3 & 3 & $5 \%$ \\
\hline 3 & Brand/product exclusivity & 9 & 12 & $15 \%$ \\
\hline 4 & Contact with nature & 8 & 9 & $14 \%$ \\
\hline 5 & Environment protection & 11 & 19 & $19 \%$ \\
\hline 6 & Freshness & 9 & 11 & $15 \%$ \\
\hline 7 & Local/regional production & 26 & 53 & $44 \%$ \\
\hline 8 & $\begin{array}{l}\text { Low number of additives and } \\
\text { non-GMOs }\end{array}$ & 10 & 13 & $17 \%$ \\
\hline 9 & $\begin{array}{l}\text { Low resource consumption and } \\
\text { use of renewable energy }\end{array}$ & 7 & 9 & $12 \%$ \\
\hline 10 & $\begin{array}{l}\text { Maintaining or regaining health } \\
\text { and adopting a healthy lifestyle }\end{array}$ & 32 & 74 & $54 \%$ \\
\hline 11 & $\begin{array}{l}\text { Manufacturing technology and } \\
\text { production/processing process }\end{array}$ & 24 & 52 & $41 \%$ \\
\hline 12 & Naturalness and purity & 15 & 23 & $25 \%$ \\
\hline 13 & Nutritional and sanitary values & 17 & 28 & $29 \%$ \\
\hline 14 & Positive emotions and feelings & 9 & 14 & $15 \%$ \\
\hline 15 & Quality & 35 & 75 & $59 \%$ \\
\hline 16 & Raw food & 7 & 11 & $12 \%$ \\
\hline 17 & Safety & 10 & 13 & $17 \%$ \\
\hline 18 & Taste & 22 & 34 & $37 \%$ \\
\hline Number of companies included in \\
the investigated group
\end{tabular}


Due to the fact that the investigated group of companies includes only processors of organic products, $44 \%$ of enterprises highlight on their websites that production/processing is done locally, the products being promoted as Romanian/ local/traditional. The quality of the products, the main positioning bases identified, is supported by the manufacturing technology and the production/ processing process, a variable that is found in the content retrieved from the websites of $41 \%$ of the analyzed companies.

As a result of the fact that the analysis is carried out for organic food brands, it is understandable why the variable "taste" is among the variables frequently communicated by the analyzed websites. Other variables that may be specific to the brands present on this market are those related to the nutritional and sanitary values of organic products, as well as the promotion of naturalness and purity of the product, occupying the following places as importance in terms of content identified on the analyzed websites.

It should be noted that 12 of the identified variables are found in less than $20 \%$ of the analyzed companies. This category includes most variables that can be linked to providing benefits to consumers (with the exception of the variable "maintaining or regaining health and adopting a healthy lifestyle"), namely: "environmental protection", "safety", "product/brand exclusivity", "positive emotions and feelings", "contact with nature" and "animal welfare". On the other hand, the variable "freshness" is more difficult to use, given that most companies process the food they sell under their own brand. Also, a small number of companies have the opportunity to manufacture organic food through thermal processing at low temperatures (below $42^{\circ} \mathrm{C}$ ), which is why the variable "raw food" is so poorly highlighted in the content on the website.

The absence of chemical pesticides and mineral fertilizers $(8 \%)$, as well as the low number of additives and the lack of genetically modified organisms (17\%), were not so frequently identified in the content collected on the websites. It is also noted that efforts to produce low-resource or renewable energy products are not a priority for the companies included in the analysis or do not consider this to be so important and relevant for brand positioning, so as to communicate it to the public.

\section{Discussions}

This study identified 18 positioning bases for the investigated green brands, as they resulted from the analysis of the content identified on the corporate websites. The identified positioning bases are both attributes that are rather specific to organic food, as well as attributes that can be representative for any food. This approach may also be used for identified benefits, which are fewer in number. These results support the existence of a balanced strategy, which in the opinion of some specialists (Hartmann et al., 2005) has the most important results in generating a positive attitude towards the green brand.

In the case of a balanced positioning strategy, the socio-ecological dimension is approached with the same intensity as other bases specific of conventional products (Belz and Karstens, 2005). Choosing a combination of primary and green attributes and benefits leads to avoiding the myopia of green marketing (Ottman et al, 2006). Also, Mera (2003) considers that positioning only by using the green attribute is not usually effective, because this attribute is not the only one, nor the main attribute that the consumer requests at the time of the purchase decision. 
The current study investigates brands that represent food, leading to the emergence of specific attributes that may represent potential positioning bases. Thus, variables such as: "taste", "raw food", "low number of chemicals and GMOs", "freshness", "nutritional and sanitary values" are representative for these brands. Some of these attributes were conceptualized by von Meyer-Höfer et al. (2015), starting from EC Regulation 834/07. Regarding the benefits, one of the functional benefits can be directly associated with the category of organic food, namely "maintaining or regaining health and adopting a healthy lifestyle".

Regarding the importance of the positioning bases identified in the content presented on the analyzed websites, the most frequently used by the analyzed brands were: "quality", "maintaining or regaining health and adopting a healthy lifestyle" and "local/regional production". On the other hand, some bases signal concern for environmental protection ("absence of chemical pesticides and mineral fertilizers", "low resource consumption and use of renewable energy").

These results are in compatibility with the reasons for buying organic products declared by Romanian consumers. Numerous studies have shown that consumers are more motivated by personal benefits than by concerns for the wellbeing of society and care for the environment (Stoica, 2020). The main reason identified in most studies is related to health (Roman et al., 2015; Vietoris et al., 2016; Petrescu et al., 2017), followed by high quality and better taste of organic products (Bozga, 2015). In contrast, care for the environment is not the main reason stated by consumers (Bozga, 2015; Voicu and Iliescu, 2015; Roman et al., 2015; Petrescu et al., 2017). In this regard, Bozga and Cristea (2016) consider that vegan products could be positioned based on their purity, expressed by the lack of chemical fertilizers, growth stimulants, herbicides, pesticides, insecticides etc., while in the case of processed products, a point of differentiation is the lack of food additives.

Compared to similar conventional products, in the case of green products, a strategy of qualitative differentiation is certainly recommended. Such an approach is based on both the intrinsic qualities of organic products and the consumer's perception on organic products. In principle, belonging to the category of organic products itself is a strong distinguishing feature from conventional products. This qualitative differentiation is also made by Romanian consumers, as indicated by the research conducted by Petrescu and Petrescu-Mag (2015). This positive image of organic food is due, as indicated by the results of research conducted by Voinea and colleagues (2015), to the following factors involved: origin in organic farming, additional input of nutrients with a positive impact on health, but also reduced quantity of substances with a negative impact on it, high food safety and superior organoleptic characteristics. However, given the low level of information and the unclear image that Romanian consumers have about organic products, highlighting some attributes (points of differentiation) can be extremely useful for the success of a green brand (Bozgă, 2017).

\section{Theoretical implications}

This study contributes to the research on the positioning of green brands. Compared to previous research (Hartmann et al., 2005; Haung et al., 2008; Wang, 2016; Wang, 2017), this study serves as a first attempt to develop the topic of 
positioning existing brands in the organic food market. Therefore, the study notes the existence of specific positioning bases for the brands present in this market. The identified positioning bases refer mainly to the category of attributes, these being mainly specific characteristics of organic products.

The study contributes to the research on green brand positioning in the online environment. Also, the research studies the positioning bases communicated at the level of a single category of partners in the organic supply chain, namely organic food processors.

\section{Managerial implications}

The obtained results can provide a series of solutions for practitioners who wish to develop a brand that would be representative for their green offer, which will differentiate itself from the rest of the brands present in this market. The study offers a series of positioning bases specific to the brands on the organic food market, presenting in detail the concepts involved in all bases as well as the relationships between them. Consequently, managers have the opportunity to create a mix between them, in order to outline a balanced positioning strategy.

The results can help practitioners to communicate brand positioning in the online environment by developing appropriate strategies. Corporate websites should be seen as a tool that plays a key role in transmitting and supporting brand positioning, as well as in increasing its value. The communication of the attributes and/or benefits that describe the desired positioning must be done in a clear and consistent manner, in order to ensure that the communicated positioning coincides as closely as possible with the desired positioning.

\section{Conclusions}

This article paves the way for research into the field of green brands in the organic food market, offering a number of specific positioning bases. The study is the first that analyzes the topic of brand positioning on the organic food market in Romania. This topic is of interest to companies that are struggling in finding a distinctive place in this market.

In order to provide a realistic basis for evaluating the results of exploratory research, it is important to specify the main limitations of this study. They can be used to develop future studies that aim to deepen the topic of positioning for a green brand in the online environment.

The analysis of secondary data did not include all the enterprises that sell under their own brand organic food on the Romanian market. The research was conducted among organic food processors, but there are other categories of certified economic operators (agricultural producers, traders). Research that would include all types of certified economic operators could provide an overview of the content of positioning communicated on companies' websites and could help to identify differences in the positioning alternatives chosen for the brand.

The application of the selection criteria for the composition of the investigated group was made mainly based on the analysis of the information present on the identified websites. Although there is a certainty that all enterprises 
included in the target population are processors of organic products, in terms of compliance with the other selection criteria, the results obtained may be affected by a number of elements: lack of information on the website, incomplete presentation of information, the existence of outdated information regarding the current activity of the company, omission of information or misinterpretation by the researcher.

The research is based only on the content taken from the official websites, which cannot represent a complete picture even on the positioning disseminated by the company regarding the brand in the online environment. All the communication media used has the role of disseminating the positioning for the brand. In addition, only the content in the form of text was extracted from the websites, but it should be noted that the images, the design, the graphics of the website etc., have a role in shaping the brand positioning and influence consumer perception.

We must specify that only one researcher was involved in the creation of the codes, therefore the replicability (Krippendorff, 2013) of the codes analyzed in this paper cannot be ensured. This was possible by hiring a second researcher to work independently and apply the same coding instructions to the same units of analysis (Wang, 2016).

\section{References}

Albalact. (2020) The official website of SC Albalact SRL for Zuzu Bio brand, Retrieved from https://zuzubio.ro.

Amin, M., Uthamaputhran, S., Ali, F. (2015) The effectiveness of green product positioning and marketing strategies towards purchase intention in Malaysia, International Journal of Innovation and Learning, 17(4), 516-528.

Asioli, D., Canavari, M., Pignatti, E., Obermowe, T., Sidali, K. L., Vogt, C., Spiller, A. (2014) Sensory experiences and expectations of Italian and German organic consumers, Journal of International Food \& Agribusiness Marketing, 26(1), 13-27.

Barrena, R., Sánchez, M. (2010) Frequency of consumption and changing determinants of purchase decision: from attributes to values in the organic food market, Spanish Journal of Agricultural Research, 8(2), 251-272.

Belz, F. M., Karstens, B. (2005) Strategic and instrumental sustainability marketing in the Western European food processing industry: Conceptual framework and hypothesis, Corporate Responsibility Research Conference, Leeds, University of Leeds.

Belz, F. M., Schmidt-Riediger, B. (2009) Marketing Strategies in the Age of Sustainable Development: Evidence from the Food Industry, Business Strategy and the Environment, 19(7), 401-416.

Bozga, N. A. (2015) Consumers behavior features upon the organic products in Romania, International Conference on Marketing and Business Development, Bucharest, University of Economic Studies Publishing House.

Bozga, N. A. (2017) Modele de marketing pentru produsele ecologice de origine agricolă. (Doctoral dissertation), Bucharest, University of Economic Studies.

Bozga, N. A., Cristea, A. (2016) Defining Primary Brand Associations for the Strategic Positioning of Certified Organic Products, International Journal of Sustainable Economies Management, 5(3), 37-50. 
Brüggenwirth, B. (2006) The CSR brand positioning grid. In: Jonker J., de Witte M. (eds), Management Models for Corporate Social Responsibility, Springer, Berlin, Heidelberg, pp. 140-146.

Bursan, R., Listiana, I., Ardeno, R., Bangsawan, S., Jimad, H., Mutolib, A. (2021) Consumer attitude toward using eco-friendly plastic bags: A green marketing approach, IOP Conference Series: Earth and Environmental Science, Bandar Lampung, Indonesia

Chen, N. H., Lee, C. H., Huang, C. T. (2015) Why buy organic rice? Genetic algorithm-based fuzzy association mining rules for means-end chain data, International Journal of Consumer Studies, 39(6), 692-707.

Ćirić, M., Prodanović, R. (2013) Positioning strategy of organic food products, Ekonomija: teorija i praksa, 6(3), 33-48.

Dean, T. J., Pacheco, D. F. (2014) Green marketing: a strategic balancing act for creating value, Journal of Business Strategy, 35(5), 14-22.

Driessen, P. H., Hillebrand, B., Kok, R., Verhallen, T. M. (2013) Green new product development: the pivotal role of product greenness, IEEE Transactions on Engineering Management, 60(2), 315-326.

European Commission. (2007) Council Regulation (EC) No 834/2007 of 28 June 2007 on organic production and labelling of organic products and repealing Regulation (EEC) No 2092/91. Official Journal of the European Union, 189(1), 1-23.

Fabrica de Lapte Brassov. (2020) The official website of SC Fabrica de lapte Brasov SRL for Olympus brand, Retrieved from https://www.olympusdairy.ro/

Fillion, L., Arazi, S. (2002) Does organic food taste better? A claim substantiation approach, Nutrition \& Food Science, 32(4/5), 153-157.

Ginsberg, J. M., Bloom, P. N. (2004) Choosing the right green marketing strategy, MIT Sloan Management Review, 46(1), 79-84.

Gong, S., Sheng, G., Peverelli, P., Dai, J. (2020) Green branding effects on consumer response: examining a brand stereotype-based mechanism, Journal of Product \& Brand Management, 30(7),1033-1046.

Hartmann, P., Ibanez, V. A., Sainz, F. J. F. (2005) Green branding effects on attitude: functional versus emotional positioning strategies, Marketing Intelligence \& Planning, 23(1), 9-29.

Hartmann, P., Sainz, F. J. F., Ibáñez, V. A. (2004) Superando los límites medioambientales de la empresa: un estudio experimental del efecto del posicionamiento ecológico en la actitud hacia la marca, Cuadernos de gestión, 4(1), 83-95.

Haryanto, B., Budiman, S. (2014) The role of environmental knowledge in moderating the consumer behavioral processes toward the Green products (survey on the Green product-mind in Indonesian), Review of Integrative Business and Economics Research, 4(1), 203-216.

Hemmerling, S., Asioli, D., Spiller, A. (2016) Core organic taste: preferences for naturalness-related sensory attributes of organic food among European consumers, Journal of Food Products Marketing, 22(7), 824-850.

Hollensen, S. (2011). Global marketing: a decision-oriented approach $\left(5^{\text {th }}\right.$ ed.), Pearson Education Limited, Edinburgh Gate Harlow.

Huang, Y. C., Yang, M., Wang, Y. C. (2014). Effects of green brand on green purchase intention, Marketing Intelligence \& Planning, 32(3), 250-268. 
Insch, A. (2011) Conceptualization and anatomy of green destination brands, International Journal of Culture, Tourism and Hospitality Research, 5(3), 282-290.

lyer, P., Davari, A., Zolfagharian, M., Paswan, A. (2019) Market orientation, positioning strategy and brand performance, Industrial Marketing Management, Vol. 81, 16-29.

Jackson, K., Bazeley, P. (2019) Qualitative data analysis with NVivo (3 ${ }^{\text {th }}$ ed.), SAGE Publications Limited, London.

Janssen, M., Hamm, U. (2011) Consumer perception of different organic certification schemes in five European countries, Organic Agriculture, 1(1), 31-43.

Juwaheer, T. D., Pudaruth, S., Noyaux, M. M. E. (2012) Analysing the impact of green marketing strategies on consumer purchasing patterns in Mauritius, World Journal of Entrepreneurship, Management and Sustainable Development, 8(1), 36-59.

Kapferer, J. N. (2008) New strategic brand management: creating and sustaining brand equity long term $\left(4^{\text {th }}\right.$ ed.), Kogan Page Limited, London.

Krippendorff, K. (2013) Content analysis: An introduction to its methodology ( $3^{\text {rd }}$ ed.), SAGE Publications, Thousand Oaks, CA.

Laia's Organic. (2020) The official website of Laia's Organic, Retrieved from https://www.laias-organic.ro.

Leonidou, L. C., Fotiadis, T. A., Christodoulides, P., Spyropoulou, S., Katsikeas, C. S. (2015) Environmentally friendly export business strategy: Its determinants and effects on competitive advantage and performance, International Business Review, 24(5), 798-811.

Lin, J., Zhou, Z. (2020) The positioning of green brands in enhancing their image: the mediating roles of green brand innovativeness and green perceived value, International Journal of Emerging Markets.

MADR (2018) Operators certified in organic farming in 2018, Retrieved from https://www.madr.ro/agricultura-ecologica/operatorii-certificati-in-agriculturaecologica-2018.html.

Magnier, L., Schoormans, J., Mugge, R. (2016) Judging a product by its cover: Packaging sustainability and perceptions of quality in food products, Food Quality and Preference, 53, 132-142.

Matthes, J., Wonneberger, A., Schmuck, D. (2014) Consumers' green involvement and the persuasive effects of emotional versus functional ads, Journal of Business Research, 67(9), 1885-1893.

Mera, A. C. (2003) El etiquetado ecológico: Un análisis de su utilización como instrumento de marketing (Doctoral dissertation), Universidad de Extremadura, Badajoz.

Mishra, P., Sharma, P. (2010) Green marketing in India: Emerging opportunities and challenges, Journal of Engineering, Science and Management Education, 3(1), 9-14.

Naspetti, S., Zanoli, R. (2005) Consumers' knowledge of organic quality marks, ISOFAR Conference on "Researching Sustainable Systems, Adelaide, South Australia.

Naspetti, S., Zanoli, R. (2009) Organic food quality and safety perception throughout Europe, Journal of Food Products Marketing, 15(3), 249-266.

Ottman, J. A., Stafford, E. R., Hartman, C. L. (2006) Avoiding green marketing myopia: Ways to improve consumer appeal for environmentally preferable products, Environment: Science and Policy for Sustainable Development, 48(5), 22-36. 
Padel, S., Gössinger, K. (2008) Farmer consumer partnerships communicating ethical values: A conceptual framework (CORE Organic project no. 1897), CORE Organic, Tjele.

Petrescu, A., Oncioiu, I., Petrescu, M. (2017) Perception of organic food consumption in Romania, Foods, 6(42), 1-11.

Petrescu, D., Petrescu-Mag, R. M. (2015) Organic food perception: fad, or healthy and environmentally friendly? A case on Romanian consumers, Sustainability, 7(9), 12017-12031.

Phenalex. (2020) The official website of SC Phenalex SRL, Retrieved from https://www.phenalex.ro/.

Polonsky, M. J., Rosenberger III, P. J. (2001) Reevaluating green marketing: A strategic approach, Business Horizons, 44(5), 21-30.

QSR International. (n.d.) About cluster analysis. Retrieved from http://help-nv11. qsrinternational.com/desktop/concepts/about_cluster_analysis.htm.

Quality Natural. (2020) The official website of S.C. Quality Natural S.R.L., Retrieved from www.valeputna.ro/.

Rahbar, E., Abdul Wahid, N. (2011) Investigation of green marketing tools' effect on consumers' purchase behavior, Business Strategy Series, 12(2), 73-83.

Rex, E., Baumann, H. (2007) Beyond ecolabels: what green marketing can learn from conventional marketing, Journal of Cleaner Production, 15(6), 567-576.

Ries, A., Trout, J. (2001) Positioning: The Battle for Your Mind $\left(20^{\text {th }}\right.$ Anniversary Edition), McGraw-Hill, New York.

Roman, T., Bostan, I., Manolică, A., Mitrica, I. (2015) Profile of green consumers in Romania in light of sustainability challenges and opportunities, Sustainability, 7(6), 6394-6411.

Roosen, J., Kottl, B., Hasselbach, J. (2012) Can local be the new organic? Food choice motives and willingness to pay (No. 322-2016-11302), Agricultural and Applied Economics Association.

Saha, M., Darnton, G. (2005) Green companies or green con-panies: are companies really green, or are they pretending to be?, Business and Society Review, 110(2), 117-157.

Schiffman, L. G., Kanuk, L. L. (2007) Consumer Behavior (9th ed.), Pearson Prentice Hall, New Jersey.

Sidali, K. L., Spiller, A., von Meyer-Hoefer, M. (2016) Consumer expectations regarding sustainable food: Insights from developed and emerging markets, International Food and Agribusiness Management Review, 19(3), 141-170.

Steenis, N. D. (2019) Consumer response to sustainable packaging design. (Doctoral dissertation), Wageningen University, Wageningen.

Stoica, M. (2020) The profile of the organic food consumer in Romania: a review, BASIQ International Conference: New Trends in Sustainable Business and Consumption, Bucharest, University of Economic Studies Publishing House.

Stoica, M., Mehedințu, M., Stoian, M., Stancu, A., Filip, A., Roșca, M. I. (2020) The Organic Food Market in Romania, Emerging Trends in Marketing and Management International Conference, Bucharest, University of Economic Studies Publishing House.

Suki, N. M. (2016) Green product purchase intention: impact of green brands, attitude, and knowledge, British Food Journal, 118(12), 2893-2910. 
Taherdangkoo, M., Mona, B., Ghasemi, K. (2019) The role of industries' environmental reputation and competitive intensity on sustainability marketing strategy: Customers' environmental concern approach, Spanish Journal of Marketing-ESIC, 23(1), 3-24.

Tjahjadi, B., Soewarno, N., Hariyati, H., Nafidah, L. N., Kustiningsih, N., Nadyaningrum, V. (2020) The Role of Green Innovation between Green Market Orientation and Business Performance: Its Implication for Open Innovation, Journal of Open Innovation: Technology, Market, and Complexity, 6(4), 1-18.

Vietoris, V., Kozelová, D., Mellen, M., Chreneková, M., Potclan, J. E., Fikselová, M., Kopkáš, P., Horská, E. (2016) Analysis of consumer preferences at organic food purchase in Romania, Polish Journal of Food and Nutrition Sciences, 66(2), 139-146.

Viile Budureasca. (2020) The official website of SC VIILE BUDUREASCA SRL, Retrieved from www.budureasca.ro/.

Vlahović, B., Šojić, S. (2017) Positioning of organic food brands in consumers' minds, AgroEkonomika, 46(76), 105-117.

Voicu, M. C., lliescu, E. M. (2015) Consumer's Attitude Concerning Organic Foods, National Strategies Observer, 3(2), 139-149.

Voinea, L., Popescu, D. V., Negrea, M. T. (2015) Bune practici în educarea şi informarea noii generaţii de consumatori privind produsele alimentare ecologice, Amfiteatru Economic, 17(38), 357-375.

von Meyer-Höfer, M., Nitzko, S., Spiller, A. (2013) Expectation Gaps and HaloEffects in Organic Food Positioning: Characteristics of Organic Food from a Consumer's Point of View (No.25), Global Food Discussion Papers, GeorgAugust-Universitaet, Goettingen.

von Meyer-Höfer, M., Nitzko, S., Spiller, A. (2015) Is there an expectation gap? Consumers' expectations towards organic: An exploratory survey in mature and emerging European organic food markets, British Food Journal, 117(5), 15271546.

Wang, H. J. (2016) Green Brand Positioning in the Online Environment, International Journal of Communication, Vol. 10, 1405-1427.

Wang, H.J. (2017) A brand-based perspective on differentiation of green brand positioning: A network analysis approach, Management Decision, 55(7), 14601475.

Willer, H., Lernoud, J. (Eds.). (2019) The World of Organic Agriculture. Statistics and Emerging Trends 2019, FiBL, Frick, and IFOAM, Bonn.

Wilson, R. M., Gilligan, C. (2005) Strategic marketing management: planning, implementation \& control ( $3^{\text {rd }}$ ed), Elsevier Butterworth-Heinemann, Burlington.

Wright, S., McCrea, D. (Eds.). (2008) The handbook of organic and fair trade food marketing. John Wiley \& Sons, Oxford.

Zameer, H., Wang, Y., Yasmeen, H. (2020) Reinforcing green competitive advantage through green production, creativity and green brand image: implications for cleaner production in China, Journal of Cleaner Production, Volume 247, 1-15.

Zander, K., Hamm, U. (2010) Consumer preferences for additional ethical attributes of organic food, Food quality and preference, 21(5), 495-503. 
Zander, K., Hamm, U., Freyer, B., Gössinger, K., Hametter, M., Naspetti, S., Padel, S., Stolz, H., Stolze, M., Zanoli, R. (2010) Farmer Consumer Partnerships-How to successfully communicate the values of organic food, University of Kassel, Kassel.

Zanoli, R., Naspetti, S. (2006) The positioning of organic products: which way forward?, Retrieved from https://orgprints.org/7629/1/ZAnoli-Naspetti_Odense_06. pdf. 